\title{
Evaluation of the effects of losartan on a random pattern skin flap model in rats
}

\section{Sıçan sırt deri flebinde losartanın etkisinin değerlendirilmesi}

\author{
Cemile Nurdan ÖZTÜRK, ${ }^{1}$ Erdem TEZEL, ${ }^{1}$ Özben YALÇIN ${ }^{2}$
}

\section{BACKGROUND}

Losartan, a drug with antiinflammatory properties, has been shown to prevent ischemic injury in various organs. The purpose of the present study was to investigate the effects of losartan on ischemic skin flaps and on flap survival.

\section{METHODS}

A $3 \times 9 \mathrm{~cm}$ dorsal flap was elevated in 24 Sprague-Dawley rats. Rats received the following treatment for seven days: Group I ( $\mathrm{n}=8): 10 \mathrm{mg} / \mathrm{kg}$ losartan; Group II $(\mathrm{n}=8): 40 \mathrm{mg} /$ $\mathrm{kg}$ losartan; and Group III $(\mathrm{n}=8)$ : nonionized water. At the end of the seventh day, the viable flap areas were calculated, and histological analysis was conducted to count cells and capillaries in microscopic fields.

\section{RESULTS}

Mean flap survival was $61 \%, 56 \%$ and $60 \%$ in Groups I, II and III, respectively. Comparison of flap survival between groups did not yield any significant difference $(\mathrm{p}>0.05)$. Ischemic zones of the flaps in all groups demonstrated an increase in number of neutrophils, fibroblasts and capillaries $(p<0.05)$, whereas no difference was seen in mast cells. The cell counts in the viable areas of the flaps showed a significant decrease in fibroblasts in the group treated with 40 $\mathrm{mg} / \mathrm{kg}$ losartan $(\mathrm{p}<0.05)$. The number of neutrophils, mast cells and capillaries was not influenced by treatment.

\section{CONCLUSION}

Losartan does not improve skin flap survival but it has a significant antiproliferative effect on fibroblasts.

Key Words: Angiotensin; AT1; fibroblast; flap survival; ischemic flap; ischemia- reperfusion; losartan; reperfusion injury.

\begin{abstract}
$A M A C ̧$
Losartanın enflamasyonu baskılayarak çeşitli organlarda iskemi-reperfüzyon hasarını azalttığı ve enfarkt alanını küçülttüğü ortaya konmuştur. Bu çalışma, losartanın deri fleplerindeki iskemik bölgeye ve flep sürvisine etkisini ortaya koymak amaciyla planland.
\end{abstract}

\section{GEREÇ VE YÖNTEM}

Sprague-Dawley sıçanlarda $(\mathrm{n}=24) 3 \times 9 \mathrm{~cm}$ boyutlarında kaudal pediküllü sırt flebi kaldırıldı. Sıçanlar 3 gruba ayrılarak 1 . gruba $10 \mathrm{mg} / \mathrm{kg}$, 2. gruba $40 \mathrm{mg} / \mathrm{kg}$ losartan ve 3 . gruba distile su verildi. Yedi günlük tedavinin sonunda fleplerdeki canlı doku alanı hesaplanarak gruplar arasında karşılaştırıldı. Ek olarak fleplerin proksimal ve iskemik bölgelerinde nötrofiller, fibroblastlar, mast hücreleri ve kapillerler sayıldı.

\section{BULGULAR}

Fleplerdeki canlı doku alanları ortalaması 1., 2. ve 3. gruplarda sirasiyla $\% 61, \% 56$ ve $\% 60$ olarak hesaplandı. Gruplar flep sağkalımı açısından karşılaştırıldığında anlam$l_{1}$ fark bulunmadı $(p>0,05)$. Tüm gruplarda fleplerin iskemik bölgesinde nötrofil, fibroblast ve kapillerlerde anlam$l_{1}$ artış saptanırken $(p<0,05)$, mast hücre sayısında fark bulunmadi. $40 \mathrm{mg} / \mathrm{kg}$ losartan ile tedavi alan grupta fleplerin yaşayan bölgesinde fibroblast sayısı anlamlı olarak azaldı $(p<0,05)$. Nötrofil, mast hücreleri ve kapiller sayıları ise tedaviden etkilenmedi.

\section{SONUÇ}

Losartan sıçan sırt deri flebinin sürvisini arttırmamakta ancak fibroblastlar üzerine anlamlı antiproliferatif etkisi bulunmaktadır.

Anahtar Sözcükler: Anjiyotensin; AT1; flep sürvisi, fibroblast; iskemik flep; iskemi reperfüzyon; losartan; reperfüzyon hasarı. 
Random flaps are frequently used in plastic surgery to reconstruct tissue defects. Skin necrosis that may occur at the distal portion of the flap is a main concern when designing such flaps. Various prophylactic and therapeutic measures have been utilized to enhance flap survival, but the search for a reliable and efficient technique continues.

Random pattern flaps undergo a gradient ischemia, which causes diminished blood flow at the distal end of the flap, and a cascade of events that are similar to ischemia-reperfusion injury are triggered. ${ }^{[1,2]} \mathrm{Neu}-$ trophils accumulate at the distal portions of random flaps, and they have important contributions to ischemic damage. ${ }^{[1-3]}$ Surgical techniques such as flap delay procedures ${ }^{[4,5]}$ have been employed to improve flap survival, and many drugs have been tested in the search for decreasing ischemic damage. ${ }^{[2,6-11]}$

The renin angiotensin system (RAS) is a regulator of blood pressure with well- known effects on the kidneys and vessels. Recently, local angiotensin receptors have been demonstrated in many organs including the skin, ${ }^{[12-15]}$ which are upregulated during ischemia. ${ }^{[12,14]}$ Activation of these receptors causes an increase in inflammatory response. ${ }^{[12,16-19]}$ Losartan, which is an angiotensin type 1 (AT1) receptor blocker, has antiinflammatory properties via acting on local systems. Zhu and Sato et al. showed this drug's ability to reduce the area of infarction in the myocardium. ${ }^{[20,21]}$ Moreover, losartan prevents ischemia-reperfusion injury in many organs including the heart, ${ }^{[16,22]}$ liver, ${ }^{[12]}$ lungs, ${ }^{[23]}$ endothelium, ${ }^{[24]}$ brain, ${ }^{[25]}$ and large intestine. ${ }^{[19]}$

We hypothesize that ischemic damage in the skin may also be decreased if proinflammatory properties of angiotensin were inhibited. In this study, the effects of losartan on ischemic skin flaps and its possible role in improving flap survival were investigated. Additionally, the influence of the drug on individual cell lines was researched.

\section{MATERIALS AND METHODS}

Twenty-four male Sprague-Dawley rats weighing between 270-350 g were used in this study. The rats were fed with rat chow and drinking water and kept in individual cages during the experiment. Study approval was obtained from the ethical committee responsible for work with laboratory animals at Marmara University Faculty of Medicine.

The rats were divided into three groups with eight rats in each group $(\mathrm{n}=8)$. Group I received $10 \mathrm{mg} / \mathrm{kg}$ losartan, Group II received $40 \mathrm{mg} / \mathrm{kg}$ losartan and Group III received nonionized water (control group). The doses were determined based on previous studies, which calculated the amount of drug that inhibited the RAS without causing hypotension. ${ }^{[20,26]}$ Losartan was dissolved in nonionized water and administered via an orogastric tube, with the first dose being 24 hours prior to elevation of the flap. The treatment was continued for seven days postoperatively.

The rats were anesthetized using ketamine $(75 \mathrm{mg} /$ $\mathrm{kg})$ and xylazine $(10 \mathrm{mg} / \mathrm{kg})$ administered by intraperitoneal injection. Following induction of anesthesia, the dorsal regions were shaved and $3 \times 9 \mathrm{~cm}$ caudally based McFarlane flaps ${ }^{[5,27]}$ were elevated with the panniculus carnosus muscle underneath. Iliolumbar arteries at the pedicle of the flap were cauterized to make the flap pure random pattern. ${ }^{[28]}$ The flaps were sutured back to the wound bed immediately.

\section{Evaluation Methods}

\section{Flap survival}

Animals were followed for a total of seven days, at which time viable and necrotic portions of the flaps were evident. Rats were sacrificed and the surviving surface area of the flaps was measured with a centimeter grid. Calculating the viable areas instead of contracted necrotic portions was preferred because it yields a more accurate result. ${ }^{[2,4,29]}$

\section{Histological analysis}

The flaps were excised and a longitudinal strip 2 $\mathrm{mm}$ in width from the middle part of the flap (thereby avoiding incision lines) was removed for histopathologic examination. The specimens were fixed in $10 \%$ formaldehyde, stained with hematoxylin- eosin and toluidine blue and examined under light microscope by the same pathologist in a random and blinded fashion. Five microscopic fields under 40X magnification were randomly picked in the proximal (adjacent to pedicle) and ischemic (adjacent to necrotic area) zones of the flap to count neutrophils, fibroblasts, mast cells, and capillaries. The counts were made in the dermis and subcutaneous planes, and mean values were calculated for each group and each zone.

\section{Statistical analysis}

Mean values were compared between groups with paired-t, unpaired-t, Wilcoxon, and Mann-Whitney U tests using computer software. The data are presented as mean \pm standard deviation in the figures. Statistical significance was set at $\mathrm{p}<0.05$.

\section{RESULTS}

On the seventh day, the regions of survival and necrosis were clearly demarcated in all groups. The necrotic portions (black scab-like tissue with no bleeding) covered approximately $1 / 3$ of the distal portion of the flaps. Microscopic examination revealed coagulation necrosis in this area with no viable cells and almost completely obstructed vessels. An ischemic zone with epidermal irregularity, dermal cellular infiltration and vascular proliferation was seen just proximal to the necrotic area (Fig. 1). Neutrophils, which were the 
Table 1. Mean area and percent survival of flaps in the three groups

\begin{tabular}{lcc}
\hline Group & $\begin{array}{c}\text { Mean area of survival in } \mathrm{cm}^{2} \\
\text { (total flap area }=27 \mathrm{~cm} \text { ) }\end{array}$ & Mean survival (\%) \\
\hline $10 \mathrm{mg}$ Losartan $(\mathrm{n}=8)$ & $16.43 \pm 2.50$ & 61 \\
$40 \mathrm{mg}$ Losartan $(\mathrm{n}=8)$ & $15.23 \pm 1.64$ & 56 \\
Control $(\mathrm{n}=8)$ & $16.31 \pm 1.25$ & 60 \\
\hline
\end{tabular}

dominant cell type, were accumulated in the dermis, while degranulated mast cells were observed mostly in the subcutaneous plane.

\section{Flap Survival}

At the end of the seventh day, mean viable flap percentages for Groups I, II and III were $61 \%, 56 \%$ and $60 \%$, respectively. The survival areas were compared between study groups and no significant difference was found. The results are summarized in Table 1.

\section{Histological Evaluation}

Comparison of proximal and

ischemic zones of flaps

Ischemic zones of the flaps in both the treatment and control groups demonstrated an increase in the numbers of neutrophils, fibroblasts and capillaries $(p<0.05)$, whereas no change was seen in mast cells (Fig. 2).

\section{Comparison of proximal zones of flaps between the three groups}

The numbers of neutrophils, mast cells and capillaries in the proximal zone were compared between treatment and control groups, and no statistical difference was found (data not shown). The number of

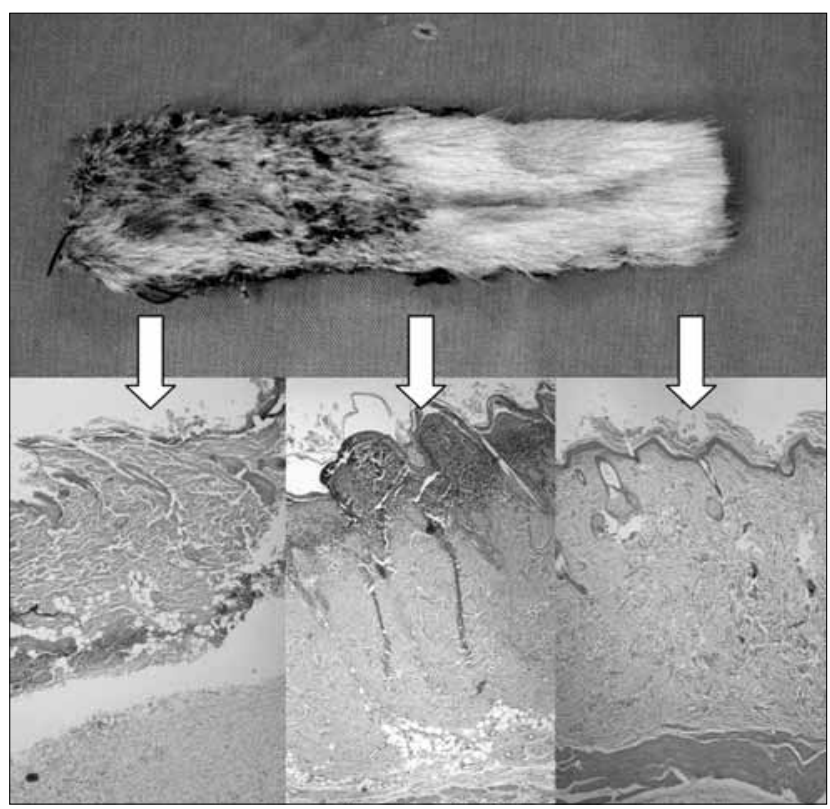

Fig. 1. The distal, middle and proximal zones of the flap in 4X magnification stained with hematoxylin-eosin. fibroblasts in the proximal zone was lowest in Group II (40 mg losartan) in comparison to Group I (10 mg losartan) and the control group ( $\mathrm{p}<0.05)$ (Fig. 3).

\section{Comparison of ischemic zones of flaps between the three groups}

The numbers of neutrophils, mast cells, capillaries, and fibroblasts in the ischemic zone were compared between the treatment and control groups, and no statistical difference was found (data not shown).

\section{DISCUSSION}

In random pattern flaps, flap survival depends on the subdermal plexus in the first postoperative days. ${ }^{[1]}$ If the blood supply is compromised during this period, an incomplete ischemia develops in the distal part of the flap that allows for accumulation of neutrophils. ${ }^{[1-3]}$ Neutrophils play a pivotal role in ischemic injury by causing direct cellular damage, forming microvascular plugs and releasing mediators such as cytokines, proteases and oxygen-derived free radicals. ${ }^{[2,3,6,10,16]}$ Inhibition of neutrophil functions has been shown to improve flap survival. ${ }^{[2,4,6,10]}$ We hypothesized that AT1 blockers may improve flap survival by inhibiting adhesion of neutrophils to the endothelium, ${ }^{[16,17,19]}$ decreasing tumor necrosis factor (TNF) alpha and interleukin (IL)-8 levels, ${ }^{[12,15]}$ modifying nitric oxide production, ${ }^{[16]}$ inhibiting platelet aggregation, ${ }^{[30,31]}$ and preventing apoptosis. ${ }^{[21,24,25]}$ Despite our expectations, comparison of flap survivals did not yield any differences between the study groups. There might be several reasons for the failure to show a beneficial effect of the drug on skin flaps. Previous studies that showed losartan's ability to reduce ischemic damage were done on organ models such as the myocardium, ${ }^{[16,22]}$ endothelium, ${ }^{[24]}$ liver, ${ }^{[12]}$ brain,,${ }^{[25]}$ and large intestine. ${ }^{[19]}$ Although AT1 receptors are present on rat skin, ${ }^{[32,33]}$ the literature is devoid of any studies about losartan's effect on these receptors. Also, the studies mentioned above were done on ischemia-reperfusion models. The gradient ischemia of random flaps constitutes a state similar to ischemia-reperfusion injury because the diminished blood flow at the distal end allows accumulation of inflammatory cells. However, the flap model we chose might have failed to fully represent ischemia-reperfusion injury, and this may be another reason for the lack of positive results. Additionally, the doses selected might have been insufficient to exert 


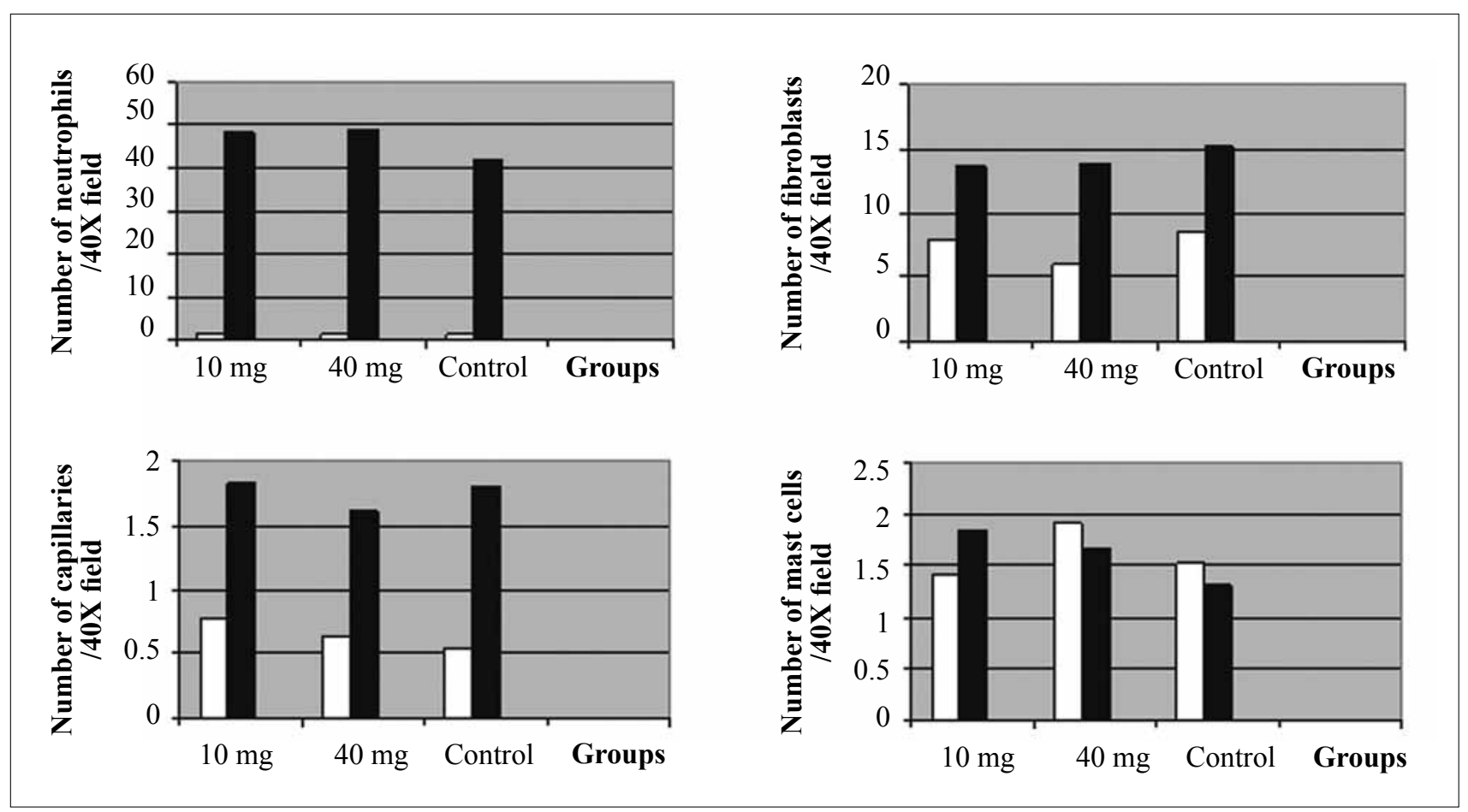

Fig. 2. Comparison of proximal ( $\square$ ) and ischemic zones ( $\mathbf{a})$ of flaps in the three groups.

an effect to improve skin flap survival. Finally, there are issues related with the wound bed. Hammond et al. ${ }^{[4]}$ demonstrated that a portion of random flaps may survive as a graft, which is a reason for the unreliable and inconsistent results in many random flap studies. Insertion of a silicone sheet under the flap is a method that prevents contact of flap with the wound bed, but this method is known to cause foreign body reactions and increase inflammation, which in turn could have biased the results. ${ }^{[34]}$

Further histological analysis was conducted to investigate the effect of losartan on cell lines. The results showed that the drug had no influence on the number of neutrophils, mast cells or capillaries, but there was a significant decrease in the number of fibroblasts in Group II (treated with $40 \mathrm{mg} / \mathrm{kg}$ losartan). These results will be discussed individually.

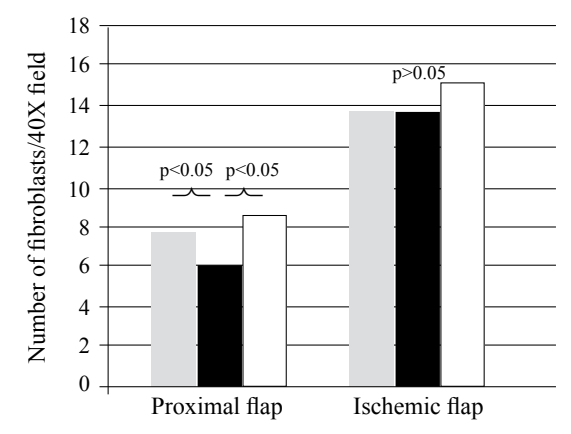

Fig. 3. Comparison of fibroblasts between the three groups. [( $) 10 \mathrm{mg},(\square) 40 \mathrm{mg},(\square)$ Control].
The decrease in the number of fibroblasts is consistent with previous studies that demonstrated an antiproliferative effect of losartan on fibroblasts, ${ }^{[35-37]}$ but its confinement to the proximal zone of the flaps is interesting. This zone-limited effect is a proof of perfusion of the drug to the viable tissues; however, perfusion to the ischemic area remains questionable. Moreover, Viswanathan and Steckelings et al. have shown an upregulation of only AT2 receptors on rat skin fibroblasts during wound healing. ${ }^{[13,32]}$ Therefore, it is possible that subtype AT2 receptors were the only receptors increased in the ischemic zone, which explains losartan's inability to exert an effect. Thus, this study supports the antiproliferative effect of losartan on fibroblasts, but more studies should be carried out to test whether the drug is effective on various models of fibrosis or scar formation.

Losartan has well-known inhibitor actions on neutrophils in various organs such as the heart, ${ }^{[16]}$ liver, ${ }^{[12]}$ mesenteric venules, ${ }^{[17]}$ large intestine, ${ }^{[19]}$ and stomach. ${ }^{[15]}$ The drug acts via suppression of neutrophil functions (rolling, adhesion, migration) and causes an eventual decrease in extravascular infiltration. In the study presented, the neutrophil accumulation in the dermis and subcutaneous planes was evaluated, and there was no difference between the treatment and control groups. Losartan's failure to limit the extravascular neutrophil flux is an explanation for the unimproved flap survival. In the studies cited above, the dose and duration of therapy and method of administration of losartan were varied, which can also ex- 
plain the contradictory results. The dose of the drug we selected might have been insufficient for inhibiting inflammation in a skin flap model.

Another finding in our study is about the role of mast cells in ischemia. Viable and ischemic areas of flaps were compared to evaluate cellular changes. An extravascular accumulation of neutrophils and fibroblasts was observed in ischemic areas, but there was no change in the number of mast cells. Although mast cells have been reported as contributors to ischemic insult, ${ }^{[38]}$ such a relation could not be shown here.

This study has several results concerning angiogenesis. Comparison of treatment and control groups yielded no significant difference in the number of capillaries, and losartan was found to be ineffective on angiogenesis. In the literature, there are controversial reports about the timing of angiogenesis after flap surgery or wound healing. Some of the studies claim an increase in angiogenesis after the first week ${ }^{[39,40]}$ while others report an onset as early as the second day. ${ }^{[1,38]}$ Our findings advocate an early onset of angiogenesis since the increase in the number of capillaries was already evident on the seventh day.

In studies investigating ischemia of flaps, a drug can be found to be effective in one study but ineffective in another. This could result from dissimilar laboratory environments, different administration methods, varying doses of drugs, various models of ischemia, insufficient perfusion of the drug to the flap, or survival of a part of the flap as a graft. ${ }^{[4,38]}$ Subsequent experiments with different methods or flap models can be conducted to see whether the results will support our findings. Additionally, it may be useful to evaluate the effects of losartan simultaneously in skin flaps and viscera, thereby investigating the tissue specificity of the drug.

In conclusion, administration of losartan in the doses and methods selected in this study did not improve random flap survival, but the drug was found to be effective in reducing the number of fibroblasts.

\section{REFERENCES}

1. Vedder NB. Flap physiology. In: Mathes SJ, editor. Mathes plastic surgery. 2nd ed. Philadelphia: Saunders Elsevier; 2006. p. 483-506.

2. Vedder NB, Bucky LP, Richey NL, Winn RK, May JW Jr. Improved survival rates of random flaps in rabbits with a monoclonal antibody that blocks leukocyte adherence. Plast Reconstr Surg 1994;93:1035-40.

3. Rees R, Punch J, Shaheen K, Cashmer B, Guice K, Smith DJ Jr. The stress response in skin: the role of neutrophil products in preconditioning. Plast Reconstr Surg 1993;92:110-9.

4. Hammond DC, Brooksher RD, Mann RJ, Beernink JH. The dorsal skin-flap model in the rat: factors influencing survival. Plast Reconstr Surg 1993;91:316-21.

5. McFarlane RM, Deyoung G, Henry RA. The design of a pedicle flap in the rat to study necrosis and its prevention. . Plast
Reconstr Surg 1965;35:177-82.

6. Cetinkale O, Sengul R, Bilgic L, Bolayirli M, Senel O, Burcak G. Involvement of neutrophils in ischemic injury. I. Biochemical and histopathological investigation of the effect of FK506 on dorsal skin flaps in rats. Ann Plast Surg 1997;39:505-15.

7. Kargi E, Deren O, Babuccu O, Hosnuter M, Erdogan B. Dual synergistic effect: the effect of dexamethasone plus carnitine on skin flap survival. Ann Plast Surg 2004;53:488-91.

8. Akamatsu J, Ueda K, Tajima S, Nozawa M. Sulfatide elongates dorsal skin flap survival in rats. J Surg Res 2000;92:369.

9. Sarifakioglu N, Gokrem S, Ates L, Akbuga UB, Aslan G. The influence of sildenafil on random skin flap survival in rats: an experimental study. Br J Plast Surg 2004;57:769-72.

10. Galla TJ, Saetzler RK, Hammersen F, Messmer K. Increase in skin-flap survival by the vasoactive drug buflomedil. Plast Reconstr Surg 1991;87:130-8.

11. Khouri RK, Brown DM, Leal-Khouri SM, Tark KC, Shaw WW. The effect of basic fibroblast growth factor on the neovascularisation process: skin flap survival and staged flap transfers. Br J Plast Surg 1991;44:585-8.

12. Guo L, Richardson KS, Tucker LM, Doll MA, Hein DW, Arteel GE. Role of the renin-angiotensin system in hepatic ischemia reperfusion injury in rats. Hepatology 2004;40:583-9.

13. Steckelings UM, Wollschläger T, Peters J, Henz BM, Hermes B, Artuc M. Human skin: source of and target organ for angiotensin II. Exp Dermatol 2004;13:148-54.

14. Yang BC, Phillips MI, Ambuehl PE, Shen LP, Mehta P, Mehta JL. Increase in angiotensin II type 1 receptor expression immediately after ischemia-reperfusion in isolated rat hearts. Circulation 1997;96:922-6.

15. Bregonzio C, Armando I, Ando H, Jezova M, Baiardi G, Saavedra JM. Anti-inflammatory effects of angiotensin II AT1 receptor antagonism prevent stress-induced gastric injury. Am J Physiol Gastrointest Liver Physiol 2003;285:G414-23.

16. de Gusmão FM, Becker C, Carvalho MH, Barros LF. Angiotensin II inhibition during myocardial ischemia-reperfusion in dogs: effects on leukocyte infiltration, nitric oxide synthase isoenzymes activity and left ventricular ejection fraction. Int J Cardiol 2005;100:363-70.

17. Alvarez A, Piqueras L, Bello R, Canet A, Moreno L, Kubes $\mathrm{P}$, et al. Angiotensin II is involved in nitric oxide synthase and cyclo-oxygenase inhibition-induced leukocyte-endothelial cell interactions in vivo. Br J Pharmacol 2001;132:67784.

18. Siragy HM, Awad A, Abadir P, Webb R. The angiotensin II type 1 receptor mediates renal interstitial content of tumor necrosis factor-alpha in diabetic rats. Endocrinology 2003;144:2229-33.

19. Riaz AA, Wang Y, Schramm R, Sato T, Menger MD, Jeppsson $\mathrm{B}$, et al. Role of angiotensin II in ischemia/reperfusioninduced leukocyte-endothelium interactions in the colon. FASEB J 2004;18:881-3.

20.Zhu B, Sun Y, Sievers RE, Browne AE, Pulukurthy S, Sudhir $\mathrm{K}$, et al. Comparative effects of pretreatment with captopril and losartan on cardiovascular protection in a rat model of ischemia-reperfusion. J Am Coll Cardiol 2000;35:787-95.

21. Sato M, Engelman RM, Otani H, Maulik N, Rousou JA, Flack JE 3rd, et al. Myocardial protection by preconditioning of heart with losartan, an angiotensin II type 1-receptor blocker: implication of bradykinin-dependent and bradykinin-independent mechanisms. Circulation 2000;102:III346- 
51.

22.Zhu P, Zaugg CE, Hornstein PS, Allegrini PR, Buser PT. Bradykinin-dependent cardioprotective effects of losartan against ischemia and reperfusion in rat hearts. J Cardiovasc Pharmacol 1999;33:785-90.

23. Raiden S, Nahmod K, Nahmod V, Semeniuk G, Pereira Y, Alvarez C, et al. Nonpeptide antagonists of AT1 receptor for angiotensin II delay the onset of acute respiratory distress syndrome. J Pharmacol Exp Ther 2002;303:45-51.

24. Barsotti A, Di Napoli P, Taccardi AA, Spina R, Stuppia L, Palka G, et al. MK-954 (losartan potassium) exerts endothelial protective effects against reperfusion injury: evidence of an e-NOS mRNA overexpression after global ischemia. Atherosclerosis 2001;155:53-9.

25. Walther T, Olah L, Harms C, Maul B, Bader M, Hörtnagl $\mathrm{H}$, et al. Ischemic injury in experimental stroke depends on angiotensin II. FASEB J 2002;16:169-76.

26. Liu YH, Yang XP, Sharov VG, Sigmon DH, Sabbath HN, Carretero OA. Paracrine systems in the cardioprotective effect of angiotensin-converting enzyme inhibitors on myocardial ischemia/reperfusion injury in rats. Hypertension 1996;27:7-13.

27. Khouri RK, Angel MF, Edstrom LE. Standardizing the dorsal rat flap. Surg Forum 1982;37:590.

28. Campbell SP, Moss ML, Hugo NE. When does a random flap die? Plast Reconstr Surg 1992;89:718-21.

29. Kryger Z, Zhang F, Dogan T, Cheng C, Lineaweaver WC, Buncke HJ. The effects of VEGF on survival of a random flap in the rat: examination of various routes of administration. Br J Plast Surg 2000;53:234-9.

30. Krämer C, Sunkomat J, Witte J, Luchtefeld M, Walden M, Schmidt B, et al. Angiotensin II receptor-independent antiinflammatory and antiaggregatory properties of losartan: role of the active metabolite EXP3179. Circ Res 2002;90:770-6.

31. Li P, Ferrario CM, Brosnihan KB. Losartan inhibits throm- boxane A2-induced platelet aggregation and vascular constriction in spontaneously hypertensive rats. J Cardiovasc Pharmacol 1998;32:198-205.

32. Viswanathan M, Saavedra JM. Expression of angiotensin II AT2 receptors in the rat skin during experimental wound healing. Peptides 1992;13:783-6.

33. Abiko M, Rodgers KE, Campeau JD, Nakamura RM, Dizerega GS. Alterations of angiotensin II Receptor levels in sutured wounds in rat skin. J Invest Surg 1996;9:447-53.

34. Jones M, Zhang F, Blain B, Guo M, Cui D, Dorsett-Martin W, et al. Influence of recipient-bed isolation on survival rates of skin-flap transfer in rats. J Reconstr Microsurg 2001;17:653-9.

35. Marshall RP, Gohlke P, Chambers RC, Howell DC, Bottoms $\mathrm{SE}$, Unger T, et al. Angiotensin II and the fibroproliferative response to acute lung injury. Am J Physiol Lung Cell Mol Physiol 2004;286:L156-64.

36. Sapna S, Ranjith SK, Shivakumar K. Cardiac fibrogenesis in magnesium deficiency: a role for circulating angiotensin II and aldosterone. Am J Physiol Heart Circ Physiol 2006;291:H436-40.

37. McEwan PE, Gray GA, Sherry L, Webb DJ, Kenyon CJ. Differential effects of angiotensin II on cardiac cell proliferation and intramyocardial perivascular fibrosis in vivo. Circulation 1998;98:2765-73.

38. Ashoori F, Suzuki S, Zhou J, Nishigaki I, Takahashi R. Possible contributions of mastocytosis, apoptosis, and hydrolysis in pathophysiology of randomized skin flaps in humans and guinea pigs. Plast Reconstr Surg 1996;98:491-501.

39. Gelaw B, Levin S. Wound-induced angiogenesis and its pharmacologic inhibition in a murine model. Surgery 2001;130:497-501.

40. Harder Y, Amon M, Erni D, Menger MD. Evolution of ischemic tissue injury in a random pattern flap: a new mouse model using intravital microscopy. J Surg Res 2004;121:197205. 